Jurnal Interpretasi Hukum | ISSN: 2746-5047

Vol. 2, No. 3-Desember 2021, Hal. 531-537| Tersedia online di

https://www.ejournal.warmadewa.ac.id/index.php/juinhum

DOI: https://doi.org/10.22225/juinhum.2.3.4132.531-537

\title{
UPAYA PENCEGAHAN KEKERASAN TERHADAP ANAK DIMASA PANDEMI COVID-19
}

\author{
Ni Made Wismantari, Anak Agung Sagung Laksmi Dewi, Ni Made Puspasutari Ujianti \\ Fakultas Hukum, Universitas Warmadewa, Denpasar-Bali, Indonesia \\ nimadewismantari@gmail.com, laksmidewi29@gmail.com, puspasutarinjianti@gmail.com
}

\begin{abstract}
Abstrak
Pandemi Covid-19 telah memberi dampak terburuk yaitu meningkatnya kerentanan anak menjadi korban kekerasan. Pandemi Covid-19 menstimulasi peningkatan kasus kekerasan terhadap anak, maka dalam hal ini dibutuhkannnya sebuah perlindungan hukum guna memenuhi hak-hak yang diperoleh bagi setiap anak. Tujuan penelitian ini adalah untuk mengungkap pengaturan hukum dalam upaya pencegahan kekerasan terhadap anak dimasa pandemi covid-19 serta perlindungan hukum terhadap anak yang mendapatkan kekerasan dimasa pandemi covid-19. Metode penelitian yang digunakan dalam penelitian ini adalah penelitian hukum normatif dengan pendekatan perundang-undangan. Teknik pengumpulan bahan hukum yang digunakan dalam penelitian ini adalah studi dokumen atau bahan pustaka. Adapun sumber bahan hukum yang digunakan yaitu sumber bahan hukum primer dan sekunder. Adapun teknik analisis data dianalisis secara kualitatif dan disajikan secara deskriptif. Hasil penelitian mengungkapkan bahwa upaya pemerintah dalam pencegahan kekerasan terhadap anak dimasa Pandemi Covid-19 ditempuh melalui perlindungan hukum Preventif dengan tujuan untuk mencegah sebelum terjadinya pelanggaran dan perlindungan hukum Represif berupa sanksi seperti denda, penjara, dan hukuman tambahan yang diberikan apabila sudah terjadi sengketa atau telah dilakukan suatu pelanggaran. Hendaknya semua pihak baik keluarga dan pemerintah berupaya melindungi anak agar terhindar dari segala tindak kekerasan.
\end{abstract}

Kata Kunci: Anak, Covid-1, Pencegahan Kekerasan

\begin{abstract}
The Covid-19 pandemic has had the worst impact, namely the increased vulnerability of children to become victims of violence. The Covid-19 pandemic has stimulated an increase in cases of violence against children, so in this case a legal protection is needed to fulfill the rights obtained for every child. The purp oses of this study are to reveal legal arrangements in an effort to prevent violence against children during the COVID-19 pandemic as well as legal protection for children who experience violence during the COVID-19 pandemic. The research method used in this research is normative legal research with a statutory approach. The technique of collecting legal materials used in this research is the study of documents or library materials. The sources of legal materials used are primary and secondary sources of legal materials. The data analysis techniques were analyzed qualitatively and presented descriptively. The results of the study revealed that the government's efforts to prevent violence against children during the Covid-19 Pandemic were pursued through preventive legal protection with the aim of preventing violations before the occurrence of violations and repressive legal protection in the form of sanctions such as fines, imprisonment, and additional penalties given if a dispute has occurred or has occurred. a violation is committed. All parties, both families and the government, should try to protect children from all acts of violence.
\end{abstract}

Keywords: Covid-19, Pandemic, Prevention of Child Violence

\section{PENDAHULUAN}

Pandemi Covid-19 telah berdampak meningkatnya jumlah korban dan kerugian harta benda, meluasnya cakupan wilayah yang terkena bencana, serta menimbulkan implikasi pada aspek sosial ekonomi yang luas di Indonesia. Data Kementerian Kesehatan pada September 2020 menunjukkan penularan Covid-19 di lingkungan keluarga cukup tinggi. Penularan Covid-19 di dalam keluarga harus diwaspadai karena terdapat kelompok rentan di dalamnya yang harus dilindungi seperti perempuan, anak, ibu hamil, ibu menyusui, lanjut usia, dan disabilitas. Berdasarkan data Ketua Umum Pengurus Pusat Ikatan Dokter Anak Indonesia (IDAI) pada 25 Mei 2020, jumlah anak usia 0-17 tahun yang terpapar Covid-19 yakni Pasien Dalam Pengawasan (PDP) sebanyak 3.324 kasus, 129 anak 
berstatus PDP meninggal dunia, 584 kasus anak terkonfirmasi positif Covid-19, dan 14 anak meninggal akibat Covid-19. Sementara berdasarkan data dari Juru bicara Satgas Penanganan COVID19, Wiku Adisasmito pada Kamis (7/1/2021) kasus covid-19 pada kelompok anak usia sekolah menyumbang 8,87 persen atau sebesar 59.776 kasus dari total kasus Corona di Indonesia. Rentang usia sekolah ini dibagi menjadi 5 kelompok, yakni usia 0-2 tahun (setara Paud), 3-6 tahun (setara TK), 7-12 tahun (setara SD), 13-15 tahun (setara SMP), dan 16-18 tahun (setara SMA). Berikut daftar 3 provinsi teratas yang memiliki angka kematian tertinggi akibat Covid-19 pada anak dengan rentang usia sekolah. 0-2 tahun (setara Paud): Sulawesi Utara (6,78 persen), Nusa Tenggara Barat (4,72 persen), Nusa Tenggara Timur (4,35 persen). 3-6 tahun (setara TK): Jawa Timur (4,6 persen), Riau (0,73 persen), Kepulauan Riau (0,72 persen). 7-12 tahun (setara SD): Jawa Timur (4,6 persen), Gorontalo (1,49 persen), Sulawesi Tengah (1,47 persen), 13-15 tahun (setara SMP): Jawa Timur (4,96 persen), Gorontalo (2,08 persen), Nusa Tenggara Barat (0,85 persen), dan 16-18 tahun (setara SMA):Jawa Timur (4,62 persen), Gorontalo (1,64 persen), Aceh (1,53 persen).

Pandemi Covid-19 telah memberi dampak terburuk yaitu meningkatnya kerentanan anak menjadi korban kekerasan. Menurut Deputi Bidang Perlindungan Anak Kementerian Pemberdayaan Perempuan dan Perlindungan Anak (Kemen PPPA), kerentanan kondisi rumah tangga di masa pandemi disebabkan karena banyak anggota keluarga yang harus tinggal di rumah dalam waktu lama, permasalahan ekonomi akibat kehilangan penghasilan dan persoalan lainnya. Tidak dipungkiri bahwa permasalahan rumah tangga di masa pandemi Covid-19 salah satunya mengakibatkan anak sebagai sasaran kekerasan. Kasus kekerasan terhadap anak banyak terjadi di masa pandemi Covid-19. Kasus pembunuhan tiga orang anak oleh ibu kandungnya yang terjadi di Nias Sumatera Utara pada 9 Desember 2020. Berdasarkan hasil pemeriksaan polisi terhadap sejumlah saksi-saksi, diketahui motif pembunuhannya karena tidak kuat menanggung himpitan ekonomi. Berdasarkan data yang dihimpun melalui Sistem Informasi Online Perlindungan Perempuan dan Anak (SIMFONI PPA) pada 1 Januari6 November 2020, terdapat peningkatan jumlah kasus dan jumlah anak yang menjadi korban kekerasan. Sebelum pandemi tercatat ada 1.888 anak perempuan menjadi korban kekerasan, setelah pandemi angka ini meningkat menjadi 5.242 anak perempuan. Untuk anak laki-laki jumlahnya memang tidak sebanyak anak perempuan, tetapi tetap mengalami peningkatan, dimana sebelum pandemi terdapat 997 anak laki-laki menjadi korban kekerasan, pada masa pandemi meningkat menjadi 2.616 anak.

Pasal 1 angka 15a, Undang-undang No.35/2014 tentang Perlindungan Anak menyatakan kekerasan adalah setiap perbuatan terhadap Anak yang berakibat timbulnya kesengsaraan atau penderitaan secara fisik, psikis, seksual, dan/atau penelantaran, termasuk ancaman untuk melakukan perbuatan, pemaksaan, atau perampasan kemerdekaan secara melawan hukum. Kejahatan kekerasan dapat diartikan sebagai penggunaan kekuatan fisik dan kekuasaan, ancaman atau tindakan te rhadap diri sendiri, perorangan atau sekelompok orang atau masyarakat yang mengakibatkan memar atau trauma, kematian, kerugian psikologis, kelainan perkembangan atau perampasan hak (Anwar, 2004). Upaya pencegahan kekerasan terhadap anak tidak hanya menjadi tugas orang tua, tetapi juga pentingnya peran pemerintah dalam memberikan perlindungan terhadap anak sesuai dengan amanat undang-undang. Pasal 2 ayat (3) dan ayat (4) Undang-undang Nomor 4 Tahun 1979 tentang Kesejahteraan Anak, menyatakan bahwa anak berhak atas pemeliharaan dan perlindungan, baik semasa dalam kandungan maupun sesudah dilahirkan. Anak berhak atas perlindungan-perlindungan dari lingkungan hidup yang dapat membahayakan atau menghambat pertumbuhan dan perkembangan dengan wajar. Perlindungan Anak juga diartikan sebagai segala kegiatan yang menjamin dan melindungi anak dan hak-haknya agar dapat hidup, tumbuh, berkembang, dan berpartisipasi secara optimal sesuai dengan harkat dan martabat kemanusiaan serta mendapat perlindungan dari kekerasan dan diskriminasi (Lubis, 2020).

Anak merupakan kelompok rentan yang perlu mendapatkan perlindungan dari segala tindak kejahatan dan kekerasan sesuai ketentuan perundang-undangan sehingga hak-haknya terpenuhi khususnya di masa pandemi. Tingginya kasus kekerasan pada anak dalam bentuk kekerasan seksual dapat disebabkan oleh banyak hal diantaranya kurangnya pengawasan orangtua terhadap anak, disorientasi seksual pada orang dewasa, tidak terkontrolnya sumber informasi dan faktor sosial budaya yang masih tabu dengan pendidikan seks usia dini (Agustin et al., 2018). Anak wajib dilindungi agar mereka tidak menjadi korban tindakan siapa saja (individu, kelompok, organisasi swasta maupun pemerintah), baik secara langsung maupun secara tidak langsung (Gosita, 1989). 
Seluruh pihak sudah seharusnya ikut memastikan anak dapat terhindar dari tindak kekerasan. Tidak hanya pemerintah, tetapi juga peran orang tua, guru, keluarga, masyarakat, dan semua pihak yang berinteraksi dengan anak satgas ugsepantasnya bertanggung jawab dalam upaya pencegahan kekerasan terhadap anak. Peran pemerintah diberikan melalui regulasi dan kebijakan yang dikeluarkan sedangkan peran semua pihak yang berinteraksi dengan anak dapat diberikan melalui pengasuhan sehingga hak anak dapat terpenuhi, terwujudnya kesejahteraan berkelanjutan, ada status hukum yang jelas dan tidak hanya memenuhi materi tetapi juga kasih sayang terhadap anak. Keadaan darurat seperti bencana alam dan pandemi Covid-19 yang dialami saat ini dapat mempengaruhi peningkatan risiko anak sebagai korban kekerasan. Hal ini menarik untuk dikaji lebih dalam guna menemukan solusi untuk meminimalisir tindak kekerasan terhadap anak terutama dimasa pandemi Covid-19.

Adapun penelitian sebelumnya dari Kendedes (2020) mengungkapkan bahwa selain menaati kebijakan pemerintah, terdapat langkah maupun upaya lebih lanjut yang harus direalisasikan yang dimulai dari lingkungan keluarga, lingkungan masyarakat, maupun lingkungan pendidikan dalam rangka meminimalisir bahkan mengantisipasi kekerasan pada anak di masa pandemi. Sama halnya dengan penelitian dari Arinalhaq \& Hadiyanto (2020) yang menjabarkan bahwa kekerasan yang terjadi pada anak saat pandemi Covid-19 meningkat secara drastis. Adapun cara penanganan kekerasan terhadap anak memerlukan kerjasama dari orang tua, keluarga, masyarakat dan pemerintah. Maka dari itu fungsi pedagogi (edukasi) harus ditanamkan kepada lingkungan keluarga, sekolah, dan masyarakat agar tindak kekerasan terhadap anak tidak terjadi lagi pada masa yang akan datang. Sedangkan menurut Cahayanengdian \& Sugito (2021) mengungkapkan bahwa faktor-faktor yang memicu perilaku kekerasan yang dilakukan ibu kepada anak selama pandemi covid 19 yaitu (1) faktor emosional, ibu merasa tidak sabar dan kesulitan membangun motivasi anak saat belajar di rumah; (2) faktor ekonomi, ibu yang bekerja tidak memiliki waktu untuk menemani anak belajar dan tekanan pekerjaan membuat ibu melapiaskan emosinya kepada anak; (3) faktor kultural, ibu merasa memiliki anak dan berhak melakukan apapun pada anak. Dari fenomena tersebut maka dilakukannya penelitian yang bertujuan untuk mengungkap pengaturan hukum dalam upaya pencegahan kekerasan terhadap anak dimasa pandemi covid-19 serta perlindungan hukum terhadap anak yang mendapatkan kekerasan dimasa pandemi covid-19.

\section{METODE PENELITIAN}

Metode penelitian yang digunakan dalam penelitian ini adalah penelitian hukum normatif (normative law research) yaitu hukum dikonsepkan sebagai kaidah atau norma yang merupakan patokan berprilaku manusia yang dianggap pantas (Benuf \& Azhar, 2020). Metode penelitian normatif adalah penelitian ilmiah untuk menemukan kebenaran berdasarkan logika keilmuan hukum dari sisi normatifnya. Bahan hukum yang diperoleh dalam penelitian ini dianalisis secara kualitatif, yang menggambarkan suatu peristiwa sesuai dengan kenyataan penelitian ini dilakukan dengan cara meneliti bahan pustaka dan bahan-bahan sekunder. Sumber bahan hukum dalam penelitian ini berasal dari penelitian kepustakaan (library research). Penelitian kepustakaan dilakukan terhadap beberapa macam sumber/bahan yang dapat digolongkan atas bahan hukum primer dan bahan hukum sekunder. Bahan hukum primer yaitu bahan-bahan hukum yang mengikat yang terdiri dari Peraturan perundangundangan yang terkait dengan objek penelitian. Bahan hukum sekunder yaitu bahan pustaka yang berisikan informasi bahan primer diantara makalah, buku-buku yang ditulis para ahli, karangan berbagai panitia pembentukan hukum (law reform organization), dan lain-lain (Suratman \& Dillah, 2012). Bahan hokum sekunder yang dijadikan bahan hukum pada penelitian ini berupa buku-buku, artikel, jurnal hukum, tesis, dan surat kabar mengenai kekerasan terhdap anak di masa pandemi. Teknik pengumpulan bahan hukum yang digunakan dalam penelitian ini adalah studi dokumen atau bahan pustaka. Peneliti mengumpulkan data sekunder yang berhubungan dengan masalah yang diteliti untuk kemudian dikategorikan, dibaca, dikaji, selanjutnya dipelajari, diklarifikasi dan dianalisis dari buku-buku, literatur, artikel, karangan ilmiah, makalah, jurnal dan sebagainya yang berkaitan dengan pokok permasalahan yang dikaji. Prosedur pengumpulan bahan hukum yang akan digunakan dalam penelitian ini adalah studi kepustakaan yaitu pengumpulan data dengan jalan membaca peraturan perundang-undangan, dokumen-dokumen reasmi maupun literatur-literatur yang erat kaitannya dengan permasalahan yang dibahas. Dari data tersebut kemudian dianalisis dan dirumuskan sebagai data penunjang di dalam penelitian ini. Analisa dapat dirumuskan sebagai suatu proses penguraian 
secara sistematis dan konsisten terhadap gejala-gejala tertentu. Berkaitan dengan penelitian untuk menganalisis bahan sekunder yang telah diperoleh penulis dengan teknik analisis secara deskriptifanalisis. Penelitian yang dilakukan bersifat deskriptif yaitu menggambarkan gejala-gejala di lingkungan masyarakat terhadap suatu kasus yang diteliti, pendekatan yang dilakukan yang dilakukan yaitu pendekatan kualitatif yang merupakan tata cara penelitian yang menghasilkan data deskriptif (Soekanto, 1986).

\section{HASIL DAN PEMBAHASAN}

\section{Pengaturan Hukum Dalam Upaya Pencegahan Kekerasan Terhadap Anak Dimasa Pandemi} Covid-19

Anak adalah seseorang yang belum berusia 18 tahun dan termasuk dalam kandungan yang harus di dilindungi karena dalam dirinya melekat harkat, martabat, dan hak-hak sebagai manusia. Anak merupakan salah satu kelompok rentan yang mengalami kekerasan dimasa pandemi Covid-19. Untuk itu diperlukan pengaturan hukum dalam upaya pencegahan kekerasan terhadap anak terutama dimasa pandemi ini. Secara spesifik belum ada pengaturan hukum terkait pencegahan kekerasan terhadap anak dimasa pandemi Covid-19, namun peraturan perundangan yang ada masih relevan diterapkan dimasa pandemi ini.

Pemerintah Pusat dan Pemerintah Daerah telah menerbitkan peraturan perundangan terkait pencegahan Covid-19 yang secara tidak langsung dapat menekan angka kekerasan terhadap anak dimasa pandemi Covid-19 adapun Produk pemerintah Pusat meliputi :

1) Keputusan Presiden No 12 Tahun 2020 tentang Penetapan Bencana Non Alam Corona Viruses Desease 2019 (Covid-19) Sebagai Bencana nasional.

2) Keputusan Presiden Nomor 7 Tahun 2020 tentang Gugus Tugas Percepatan Penanganan Corona Virus Disease 2019 (COVID-19) sebagaimana telah diubah dengan Keputusan Presiden Nomor 9 Tahun 2020 tentang Perubahan atas Keputusan Presiden Nomor 7 Tahun 2020 tentang Gugus Tugas Percepatan Penanganan Corona Virus Disease 2019 (COVID-19).

3) Peraturan Pemerintah Nomor 21 Tahun 2020 tentang Pembatasan Sosial Berskala Besar Dalam Rangka Percepatan Penanganan Corona Virus Disease 2019 (COVID-19).

4) Keputusan Menteri Kesehatan Republik Indonesia nomor HK 01.07/Menkes/382/2020 tentang Protokol Kesehatan bagi Masyarakat di Tempat dan Fasilitas Umum Dalam Rangka Pencegahan dan Pengendalian Corona Virus Disease 2019 (Covid-19) .

5) Maklumat Kepala Kepolisian Republik Indonesia Nomor: Mak/2/III/2020 tentang Kepatuhan Terhadap Kebijakan Pemerintah dalam Penanganan Penyebaran Virus Corona (COVID-19).

6) Peraturan Pemerintah RI (PP) Nomor 49 Tahun 2020 tentang Penyesuaian Iuran Program Jaminan Sosial Ketenagakerjaan Selama Bencana Nonalam Penyebaran Corona Virus Disease (Covid-19).

7) Peraturan Pemerintah Republik Indonesia Nomor 23 Tahun 2020 Tentang Pelaksanaan Program Pemulihan Ekonomi Nasional dalam Rangka Mendukung Kebijakan Keuangan Negara untuk Penanganan Pandemi Corona Virus Disease 2019 (Covid-19) dan/atau Menghadapi Ancaman yang Membahayakan Perekonomian Nasional dan/atau Stabilitas Sistem Keuangan Serta Penyelamatan Ekonomi Nasional.

Sedangkan Produk hukum yang dikeluarkan pemerintah daerah dalam hal ini Pemerintah Daerah Provinsi Bali meliputi :

1) Instruksi Gubernur Bali nomor 8551 tahun 2020 tentang penguatan pencegahan dan penanganan covid-19 di Bali;

2) Surat edaran Gubernur Bali nomor 487/gugascovid19/ix/2020 tahun 2020 tentang penguatan pencegahan dan pengendalian covid-19 di Bali.

3) Surat edaran Gubernur Bali nomor 730/9251/mp/bkd tahun 2020 tentang penyesuaian sistem kerja pegawai dalam upaya pencegahan penyebaran covid-19 di provinsi Bali.

4) Surat edaran Gubernur Bali nomor $730 / 7835 / \mathrm{mp} / \mathrm{bkd}$ tahun 2020 perubahan atas surat edaran gubernur bali nomor 7194 tahun 2020 tentang panduan tindak lanjut terkait pencegahan penyebaran corona virus disease 2019 (covid-19) di lingkungan pemerintah provinsi Bali.

5) Surat edaran Gubernur Bali nomor 09/satgas covid19/iii/2020 tahun 2020 pelaksanaan pembelajaran di rumah. 
6) Keputusan Gubernur Bali Nomor: 236/03-B/HK/2020 Tentang Pembentukan dan Susunan Keanggotaan Satuan Tugas Penanggulangan Corona Virus Disease (COVID-19) di Provinsi Bali.

7) Keputusan Bersama Gubernur Bali dan Majelis Desa Adat Provinsi Bali Nomor: 472/1571/DPMA dan Nomor: 05/SKMDA-Prov. Bali/III/2020 Tentang Pembentukan Satuan Tugas Gotong Royong Pencegahan COVID-19 Berbasis Desa Adat di Bali.

Adapun pengaturan hukum yang masih relevan terkait pencegahan kekerasan terhadap anak dimasa pandemi Covid-19 sebagai berikut:

1) Undang-undang No 4 Tahun 1979 tentang Kesejahteraan Anak.

2) Undang-undang nomor 35 Tahun 2014 tentang perubahan atas Undang-undang nomor 23 tahun 2002 tentang Perlindungan Anak.

3) Undang-undang Nomor 11 Tahun 2012 Tentang Sistem Peradilan Pidana Anak.

4) Peraturan Presiden No 61 tahun 2016 tentang Komisi Perlindungan Anak Indonesia.

5) Peraturan Pemerintah Republik Indonesia Nomor 70 Tahun 2020 Tentang Tata Cara Pelaksanaan Tindakan Kebiri Kimia, Pemasangan Alat Pendeteksi Elektronik, Rehabilitasi, dan Pengumuman Identitas Pelaku Kekerasan Seksual Terhadap Anak.

\section{Perlindungan Hukum Terhadap Anak yang Mendapatkan Kekerasan Dimasa Pandemi Covid-} 19

Pasal 21 Undang-undang Nomor 35 Tahun 2014 menyebutkan bahwa negara, pemerintah, dan pemerintah daerah berkewajiban dan bertanggung jawab menghormati pemenuhan hak anak tanpa membedakan suku, agama, ras, golongan, jenis kelamin, etnik, budaya dan bahasa, status hukum, urutan kelahiran, dan kondisi fisik dan/atau mental. Berdasarkan kewajiban tersebut, terlihat jelas bahwa pemerintah melakukan upaya dalam memberikan perlindungan terhadap anak. Adapun perlindungan hukum yang diberikan adalah perlindungan hokum Preventif dan Represif.

a) Perlindungan Hukum Preventif

1. Jaminan perlindungan anak diberikan dengan perlindungan hukum sesuai Undang-undang Nomor 23 Tahun 2002 tentang Perlindungan Anak dan telah dilakukan perubahan sebanyak dua kali, yakni pada Undang-undang Nomor 35 Tahun 2014 tentang Perlindungan Anak dan Undang-undang Nomor 17 Tahun 2016 tentang Perlindungan Anak. Perubahan ini merupakan upaya pemerintah dalam pencegahan kekerasan yang sifatnya situasional terkait perkembangan kasus kekerasan terhadap anak oleh pelaku kekerasan.

2. Peraturan Pemerintah Nomor 21 Tahun 2020 tentang Pembatasan Sosial Berskala Besar Dalam Rangka Percepatan Penanganan Corona Virus Disease 2019 (COVID-19). Dampak penyebaran Corona Virus Disease 2019 (COVID-19) telah mengakibatkan terjadi keadaan tertentu sehingga perlu dilakukan upaya penanggulangan, salah satunya dengan tindakan pembatasan sosial berskala besar. Selain menekan angka penyebaran Covid-19 pembatasan sosial berskala besar diharapkan dapat menurunkan berbagai danpak negatif Covid-19 di berbagai sektor, salah satunya angka kekerasan terhadap anak dimasa pandemi.

3. Peraturan Pemerintah Republik Indonesia Nomor 70 Tahun 2020 Tentang Tata Cara Pelaksanaan Tindakan Kebiri Kimia, Pemasangan Alat Pendeteksi Elektronik, Rehabilitasi, dan Pengumuman Identitas Pelaku Kekerasan Seksual Terhadap Anak.

4. Surat Keputusan Menteri Pemnberdayaan Perempuan dan Perlindungan Anak Republik Indonesia Nomor 33 tahun 2020 tentang Tim Gerakan Bersama Jaga Keluarga Kita (BERJARAK) untuk melindungai perempuan dan anak dari bahaya penularan Covid-19. Gerakan ini dirancang untuk menghadapi fase darurat pandemi Covid-19 melalui strategi dan pendekatan secara komprehensif dan terintegrasi dengan berkoordinasi bersama kementerian atau lembaga dan dinas provinsi dan kabupaten/kota pemangku urusan PPPA di seluruh Indonesia dengan sasaran utama kelompok rentan terdampak seperti anak, perempuan, lansia dan penyandang disabilitas yang diberikan perlindungan secara adil, non diskriminatif dan bebas dari stigma. Ada 10 aksi dalam Gerakan BERJARAK, salah satunya adalah hak perempuan dan anak terpenuhi. Hal ini diimplementasikan dalam bentuk pemenuhan kebutuhan spesifik bagi perempuan dan kebutuhan spesifik anak sesuai dengan kelompok usia. Bantuan kebutuhan spesifik ini diberikan sebanyak 682 paket dengan sasaran 
perempuan, anak, ibu hamil dan menyusui, para lanjut usia dan penyandang disabilitas yang berasal dari kelompok rentan terdampak Covid 19 di seluruh kabupaten/kota di Bali melalui mekanisme kerjasama Kemen PPPA, Dinas Sosial PPPA Provinsi Bali, dan Dinas Kabupaten/Kota pengampu urusan PPPA di seluruh Bali.

b) Perlindungan Hukum Represif.

1. Pasal 76D UU 35 Tahun 2014 tentang Perlindungan Anak, Setiap Orang dilarang melakukan Kekerasan atau ancaman Kekerasan memaksa Anak melakukan persetubuhan dengannya atau dengan orang lain.

2. Pasal 81 ayat (1) UU 35 Tahun 2014 tentang Perlindungan Anak Setiap orang yang melangggar ketentuan sebagaimana dimaksud dalam Pasal 76D dipidana dengan pidana penjara paling singkat 5 (lima) tahun dan paling lama 15 (lima belas) tahun dan denda paling banyak Rp5.000.000.000,00 (lima miliar rupiah).

3. Pasal 81 ayat (3) UU 35 Tahun 2014 tentang Perlindungan Anak Dalam hal tindak pidana sebagaimana dimaksud pada ayat (1) dilakukan oleh Orang Tua, Wali, pengasuh Anak, pendidik, atau tenaga kependidikan, maka pidananya ditambah 1/3 (sepertiga) dari ancaman pidana sebagaimana dimaksud pada ayat (1).

4. Pada perubahan kedua pada UU Nomor 17 Tahun 2016 tentang Perlindungan Anak pada Pasal 81 hukuman yang diberikan adalah hukuman pidana ditambah 5 tahun dari 15 tahun menjadi 20 tahun serta diperberat dengan hukuman berupa kebiri kimia dan pemasangan alat pendeteksi elektronik.

\section{SIMPULAN DAN SARAN \\ 1. Simpulan}

Berdasarkan data kementerian PPA 2020 peiode 1 Januari sampai dengan 6 November 2020, peningkatan kekerasan sebelum dan pada masa pandemi meningkat signifikan yaitu sebesar $172 \%$ terjadi pada anak perempuan dan sebesar $168 \%$ terjadi pada anak laki-laki. Peningkatan ini pelu disikapi oleh semua pihak untuk menghindarkan anak sebagai korban kekersan. Secara spesifik belum ada pengaturan hukum terkait pencegahan kekerasan terhadap anak dimasa pandemi Covid-19, namun peraturan perundangan yang ada masih relevan diterapkan dimasa pandemi ini. Pemerintah telah menerbitkan peraturan perundangan terkait pencegahan Covid-19 yang secara tidak langsung dapat menekan angka kekerasan terhadap anak dimasa pandemi Covid-19. Adapun pengaturan hukum yang relevan terkait pencegahan kekerasan terhadap anak dimasa pandemi Covid-19 sebagai berikut: Pasal 2 Undang-undang No 4 Tahun 1979 tentang Kesejahteraan Anak; Pasal 59 Undang-undang nomor 35 Tahun 2014 tentang perubahan atas Undang-undang nomor 23 tahun 2002 tentang Perlindungan Anak; Undang-Undangan Nomor 11 Tahun 2012 Tentang Sistem Peradilan Pidana Anak; Peraturan Presiden No 61 tahun 2016 tentang Komisi Perlindungan Anak Indonesia; Pasal 2 Peraturan Pemerintah Republik Indonesia Nomor 70 Tahun 2020 Tentang Tata Cara Pelaksanaan Tindakan Kebiri Kimia, Pemasangan Alat Pendeteksi Elektronik, Rehabilitasi, dan Pengumuman Identitas Pelaku Kekerasan Seksual Terhadap Anak. Adapun negara, pemerintah, dan pemerintah daerah berkewajiban dan bertanggung jawab menghormati pemenuhan hak anak tanpa membedakan suku, agama, ras, golongan, jenis kelamin, etnik, budaya dan bahasa, status hukum, urutan kelahiran, dan kondisi fisik dan/atau mental. Perlindungan hukum yang diberikan kepada subyek hukum dalam bentuk perangkat aturan hukum dan cara cara tertentu bersifat preventif dan bersifat represif. Hal tersebut merupakan representasi dari fungsi hukum itu sendiri untuk memberikan suatu keadilan, ketertiban, kepastian, kemanfaatan dan kedamaian. Upaya pemerintah dalam memberikan perlindungan hukum terhadap anak yang mendapatkan kekerasan dimasa Pandemi Covid-19 ditempuh melalui perlindungan hukum Preventif dengan tujuan untuk mencegah sebelum terjadinya pelanggaran dan perlindungan hukum Represif berupa sanksi seperti denda, penjara, dan hukuman tambahan yang diberikan apabila sudah terjadi sengketa atau telah dilakukan suatu pelanggaran. 


\section{Saran}

Upaya pencegahan kekerasan terhadap anak adalah tanggung jawab orang tua, keluarga, masyarakat, pemerintah dan negara yang dilaksanakan secara terus menerus demi terlindunginya hak-hak anak. Kepada orang tua dan keluarga hendaknya melakukan kegiatan positif yang bisa menambah kedekatan dalam keluarga dengan tetap menerapkan protokol Kesehatan misalnya menonton film, berolahraga bersama, bermain bersama anak di rumah, dan sebagainya. Semua pihak hendaknya bergandengan tangan tangan dalam upaya pencegahan kekerasan terhadap anak. Meskipun Perlindungan hukum terhadap anak yang mendapat kekerasan dimasa pandemi telah ditempempuh melalui upaya perlindungan hukum Preventif dan Represif hendaknya orang tua dan orang terdekat dengan anak bisa memainkan peran senteral melalui pola asuh yang baik sehingga kekerasan terhadap anak dimasa pandemi ini bisa diminimalisir.

\section{DAFTAR PUSTAKA}

Agustin, M., Saripah, I., \& Gustiana, A. D. (2018). Analisis Tipikal Kekerasan Pada Anak dan Faktor yang Melatarbelakanginya. Jurnal Ilmiah VISI PGTK PAUD dan DIKMAS, 13(1), 1-10.

Anwar, Y. (2004). Saat Menuai Kejahatan: Sebuah Pendekatan Sosio cultural Kriminologi Hukum. Refika Aditama, Bandung.

Arinalhaq, R., \& Hadiyanto. (2020). Peran Keluarga, Sekolah dan Masyarakat dalam Penanganan Kekerasan Terhadap Anak (Child Abuse) pada Masa Pandemi COVID-19. E-Tech, 8(2), 1-6.

Benuf, K., \& Azhar, M. (2020). Metodologi Penelitian Hukum Sebagai Instrumen Mengurai Permasalahan Hukum Kontemporer. Gema Keadilan, 7(1), 20-33.

Cahayanengdian, A., \& Sugito. (2021). Perilaku Kekerasan Ibu Terhadap Anak Selama Pandemi Covid 19. Jurnal Obsesi : Jurnal Pendidikan Anak Usia Dini, 6(3), 1180-1189.

Gosita, A. (1989). Masalah Perlindungan Anak. Akademi Pressindo, Jakarta.

Kendedes, I. (2020). Kekerasan Terhadap Anak di Masa Pandemi Covid. Jurnal ARKAT, 16(1), 6676.

Lubis, M. A. (2020). Perlindungan Hak Dasar Anak pada Masa Pandemi Covid-19 di Kota Medan. Jurnal Mercatoria, 13(2), 188-203.

Suratman, \& Dillah, P. (2012). Metode Penelitian Hukum. Alfabeta, Bandung. 